\title{
BETWEEN TRANSMISSION AND SILENCE: RECOVERING HARKI MEMORIES IN THE ART OF LOSING
}

\begin{abstract}
Alice Zeniter's 2017 novel The Art of Losing, translated recently by Frank Wynne from French to English, explores how buried histories resurface and haunt generations to come, despite national efforts to ignore, if not minimalize, the enduring impacts of colonialism, independence struggles and exile. Set in contemporary France in the wake of the 2015 terrorist attacks, and loosely inspired by Zeniter's own family history, the book follows Naïma, a young woman of Algerian decent who grapples with a largely unknown and misconstrued harki heritage. Drawing on Marianne Hirsch's concept of postmemory, this article investigates intergenerational transmission of memory, trauma, and silence around themes such as war, exile and integration.
\end{abstract}

Keywords: French-Algerian literature; Algerian War; Harki narrative; postmemory; transgenerational trauma; exile; Generation 2.5.

Alice Zeniter's 2017 epic novel The Art of Losing, translated recently by Frank Wynne from French to English, investigates how concealed histories reemerge and haunt subsequent generations, despite national efforts to disregard, if not minimalize, the enduring impacts of colonialism, independence struggles and exile. Set in contemporary France and loosely inspired by the author's own family history, the tale begins and ends with 29-year-old Naïma, as she seeks to "fill the silences handed on with the vignettes from one generation to the next" (Zeniter 16). The novel encompasses three distinct and interweaving sections spanning across three generations. It is anchored in her grandfather Ali's experiences in a colonized Algeria, follows her family's post-independence exile and difficult installation in the reception camps of "Cold France" as well as her father's successful yet painful assimilation story, and finally, Naïma's physical "return" to Algeria in the 2010s.

Zeniter, who has undertaken extensive personal and historical research in

* Boston University, Massachusetts; USA. 
order to write the book, inserts an impressive array of past events and archives pertaining to Algeria and France within the fictional narrative frame. She melds her two-fold intention to resurge personal and collective memories from the complicated depths of repression, silence, misrepresentation and invisibility. In Naïma's semi-fictional quest to free the silences within her Algerian bloodline, Zeniter thus concurrently participates in dismantling France's long-time occlusion of Algerian histories. On the one hand, France has done considerable memory work since the turn of the $20^{\text {th }}$ century, as indicated by the official naming of the Algerian War (1954-62) and recognition of multiple traumatic events, such as the Sétif massacre of 1945 . While these remembrances have prompted a necessary and painful re-examination of collective memory (coined the memory wars), the repression of nearly two centuries of acknowledgement and remembrance has turned into a trauma at the personal, national and transnational level. ${ }^{4}$ Specifically, Zeniter engages in the complicated memory politics of both France and Algeria surrounding silenced harki narratives, which have remained to this day almost entirely off-frame. The term "harki" refers to any Muslim Algerian native having assisted the French army during the Algerian War. But it has also evolved into an inherited label that extends across all family members and descendants of the said original harki. Both France and Algeria have historically refused to bring harki experiences to the forefront, neglecting instrumental components of French and Algerian history and heritage. It was only very recently, in 2018, that President Emmanuel Macron officially recognized the harkis publicly for the first time (Chrisafis). In the same vein as Macron, Zeniter incites an inclusive memory project that acknowledges, honors, and retells harki stories.

As sociologist Jeffrey Prager observes, this history of forgetting and Othering cannot be easily undone:

We are living through an age, throughout the world, of collective remembering in which political agents and various organized publics are gingerly attempting to find a way of undoing the secrets, passed from one generation to the next,

\footnotetext{
${ }^{4}$ One such affair involves the Paris Massacre of October 17, 1961, during which hundreds of peaceful protesters for Algerian independence died or went missing after brutal police attacks and drownings. This event has finally been commemorated in novels and films, but these sources continue to omit important aspects of the event.
} 
without irreparably opening old wounds This is no easy process and, it is also true to say, considerable effort is also being expended to forget and to protect a traumatic past from full-scale exposure. (150)

I posit that Zeniter, in the Art of Losing, recovers invisible wounds of the past in order to render possible processes of memory and mourning at the individual and collective level. In this paper, I examine how this young French author of Algerian descent weaves a multidimensional approach to history, memory, remembrance and postmemory, inviting new avenues for healing from the wounds of a long-forgotten past, rather than falling into the metaphorical trap of masking memory. While illuminating narrative methods of investigating intergenerational transmission of memory and excavating silenced narratives of trauma and loss, this article addresses how Zeniter's art of giving an empowered voice to the devastating silence and loss that has been passed down from one generation to the next.

\section{Revisiting Silenced Trauma through Postmemory}

Marianne Hirsch, in her pioneering research on postmemory, examines the role of intergenerational transmission of trauma, focusing on the Jewish experience of the Holocaust and the manner in which cultural and personal tragedies have continued to haunt subsequent generations. Members of generation 2.5, a term used to describe children of parents who were themselves children at the time of the original traumatic episode, often become indirect carriers of their parents' and grandparents' traumas, which live on as enigmatic yet omnipresent hauntings of the past. In turn, these hauntings perpetuate themselves through repetitive repression and continued silence at a personal as well as a public level. Naïma can be considered amongst those of generation 2.5, as her father Hamid was only a young boy when he left Algeria to enter a refugee camp in France. Naïma in fact remains unaware of her inherited and unknown identity as a harki, until she begins questioning her origins and researches the word in a dictionary:

When she gets home, she picks up the copy of Larousse lying on the shelf...She opens it to the letter $H$ and reads harki, n.: 
Re-writing, Re-imagining the Past (III)

A soldier serving in the Harka auxiliaries.

harki, n. And adj.,

A family member or descendant of a harki.

"No way," she says to the book. "It is out of the question." (Zeniter 341)

In a deciding, split moment, the young woman thus learns of the inherited identity she occupies that has been deliberately stifled and stigmatized from the outset. Contradictorily, a term that she had never heard before is meant to define her, signalling how unaware she is of her family history due to the intertwining of silence, stigma and identity politics. Further investigation leads Naïma to disconcerting and outright brutal commentary from uncensored websites castigating her and threatening her for this heritage. Adding to this complicated and painful harki intrigue is the fact that Zeniter writes in the wake of the 2015 terrorist attacks in Paris, which inevitably elevated racism and xenophobia against Muslim populations in France. ${ }^{5}$

For Naïma to move forward in life and uncover the traumatic silences of the past that continue to haunt her and her family, the story must begin with "Papa's Algeria." Here, Zeniter reutilizes President De Gaulle's ironic famous words from 1959, "Papa's Algeria is dead," deploying them to call attention to her own family, through describing her father's and her grandfather's Algeria; in presenting this otherwise off frame lens, she accentuates that "Papa's Algeria" was never "dead," but rather actively silenced and dismantled. Naïma's father, Hamid, claims to have no recollection of Algeria, nor does he wish to recall anything beyond the dazzling, white image of Algiers as he drifted towards France (Zeniter 136). He is a source of protective silence surrounding trauma, and yet, in his silence, he paradoxically transmits the ghosts of the past to resurface forcefully within his daughter's life. As Hirsh states, "At stake is precisely the 'guardianship' of a traumatic personal and generational past with which some of us have a 'living connection' and that past's passing into history" (104). In order to understand and process this ghostly traumatic past, Hirsch, like Zeniter, stresses that traditional methodologies of artefacts such as archives will only

\footnotetext{
${ }^{5}$ Naïma's friends at the art gallery where she works instinctively and illogically lump her into a group of supposed indirect condoners to terrorism, since has not somehow publicly apologized for tragedies that she has no part in. Her friend Elise remarks "It has to be said that the Muslims haven't really condemned the attacks...It's hardly surprising that the rest of the population thinks that maybe they support them" (Zeniter 322).
} 
brush the surface of the "bodily, psychic and affective impact of trauma and its aftermath" (110), which determinedly reverberates across a minimum of three to four generations to come. Hirsch explores photography and image as means of mediation that can help fill the inherent absences of historical documentation, since they "emanate" memory and help the observer to "reconnect [to] and reembody" (110) the disconcerting subject of traumatic memory, while resurfacing the silences inherent in trauma.

Zeniter ingeniously creates missing photography pertaining to harkis through Naïma's retellings of her grandfather's life experience in Algeria and in exile, recuperating the details that have been generationally omitted. For instance, she embellishes the family's fairy tale-like origin story that she knows by heart about Ali's heroic rendering of an oil press from turbulent waters, and his ensuing rise to considerable land ownership, wealth and community respect. ${ }^{6}$ But also, Zeniter brings to the forefront historical details of national traumas that remain largely unknown, such as the participation of men from the colonies in both WWI and WWII. ${ }^{7}$ What is at work here is a retelling of an origin story that interconnects and frees histories and stories from the reigns of silence. The novelist demonstrates the importance of revisiting the initial mental and physical effects of deep trauma in war, as otherwise it is psychologically relived by future generations. For instance, when Ali discovers his friend Akli's mutilated, emasculated cadaver at the Veteran's Association, where he has been brutally and unjustly massacred by members of the National Liberation Front, he undergoes a direct and violent trauma that causes a visceral paralyzing and enduring explosion within his own body:

A bomb silently explodes, a bomb that does not burst beyond the bounds of Ali's body. Shards of grief and rage ricochet inside his skin, careering off in

\footnotetext{
6 "The dark mass in hurtling toward them. The sound of roaring water and clattering stones is joined by the creak of a strange craft jolting against the rocks as it plunges downstream. Djamel and Hamza scramble out of the river; Ali does not move, but simply crouches beneath the rock he is gripping..." (Zeniter 16)

7 The only titled chapter in the novel, "Monte Casino," recapitulates the Battle of Monte Casino, which entailed four horrific and costly clashes. Soldiers of several colonized nations (Morocco, Tunisia, Algeria, India, and New Zealand) were regimented to the front lines, many of whom were killed. In unburying this tragic event, Zeniter strategically calls out highly sensitive, misunderstood and unincorporated colonial historical episodes, while simultaneously honoring the courageous individual efforts of soldiers like Ali.
} 
different directions, surging through his veins, moving faster than his pulsing blood...Fragments embedded in his flesh throb at the slightest movement" (Zeniter 86).

Such a detailed and tragic description of Ali's trauma begs that the reader ponder the following key questions: How do one's children and grandchildren continue to bear the original devastation of traumatic impact indirectly? What remains of deep trauma that has been suppressed and repressed in the "art of losing" a country, a family history, and ownership over one's self-defining personal story?

In revisiting both the tragic realities and the epic idealist tradition, Zeniter's literary alter ego, Naïma, has begun the process of what J.M Coetzee entitles "reopening the coffin," in the feat of introspectively re-imagining the past (1). By beginning the story with Ali and Algeria, Zeniter inaugurates a constructive form of postmemory that evokes present-day tensions in France, in turn offering the possibility of re-examination and reconciliation of deep-rooted and deeply buried traumas. First and foremost, the nature of the transmitted silence must be understood. Ali represents the mindset of survival and limited assimilation to France, an obligatory "forgetting" of an entire country despite not being offered a new one (Zeniter 145). Hamid resents his father for "forcing" his family to leave Algeria, only to settle by quietly and submissively occupying "the tiny space allocated to him" (Zeniter 196). Yet he also swallows his urges to break the silences out of fear, anger and renunciation. In turn, the traumas become a repressed fantasy, as they "stand like tombs in the life of the ego" (qtd. in Prager 149). These "tombs" are then passed down to Naïma, who experiences them as "a vast expanse like the images of black holes taken with a telescope" (Zeniter 352). Furthermore, Hamid's successful integration into French society widens the gap between father, son, and motherland, as it leads Hamid to surrender any vestige of his Algerian roots: religion, language and memory alike. ${ }^{8}$

\footnotetext{
8 Hamid's psychological experience of unprocessed and unspeakable trauma can be better understood through differentiating an ideal psychic process of introjection with that incorporation. When the parent undergoes interrupted introjection, that is to say, he/she is not able to put into words his/her own unfulfilled desires due to trauma, he/she passes on this absence of language to the child, rupturing the possibility of empowering and conciliatory dialogue for both generations, and creating for the child a "fantasy of incorporation." The wish that the memory of the trauma and the trauma itself had never happened leads to burying secrets that continue to haunt subsequent generations (Abraham 125-38).
} 
When Naïma asks her father what Ali did during the war, Hamid's physiological response evokes an episode similar to the one his father underwent at the moment he discovered his murdered friend:

Hamid's head explodes with a sound he has not heard since adolescence. It is like the shriek of nails on a blackboard. The sound seems so loud that he is convinced the Naïma can hear it too, that it is being transmitted from his skull to his daughter's, drilling into her ear" (Zeniter 345).

The inclusion of Naïma as semiotically hearing the sound of trauma buried within her father's brain demonstrates a potent example of the workings of postmemory and the paradigm of harrowing silence that brands Naïma as an affective carrier of traumatic memory. Still, in conjunction with the revelation of little-known episodes of Algerian history, this personal calling to return to and process the trauma, indicates Zeniter's larger project of resisting the systematic "art of losing" endured at a personal, familial, national and transnational level.

\section{The Return: Naïma's Algeria}

The story in The Art of Losing may not be solely about Naïma. But it does begin with a growing awareness that her quotidian inexplicable sensation of "I can't do this" (3) in life is intricately tied to an inherited past she must affront and re-examine. The novel also ends with a healing journey to Algeria, in which she tangibly takes possession of her family's past and her own identity. Interestingly, Naïma is encouraged to "return" to her family's motherland by older male figures outside of her own family. These characters take on a facilitative and encouraging role in recuperating healthy dialogue that has been repetitively stifled by trauma. In turn, they substitute previous generations' inability to process and master "intrusive" memories through introjection, that is, the psychic progression of moving forward and creating a "new voice, uttering new words, fulfilling a unique desire" (Prager 149). The end product becomes Naïma's empowering autonomy and independence. ${ }^{9}$

Interestingly, Zeniter breaks an expected narrative tradition in The Art of

\footnotetext{
${ }^{9}$ Ifren, her Algerian driver, recites Elizabeth Bishop's emblematic poem "One Art," which explores the gradual "art of losing" a country, allowing Naïma to intertextually put into words the painful, mysterious and complicated process of trying to find, or even produce, what has already been largely lost; it takes Zeniter 600 pages to start to fill the silences implicit in the poem.
} 
Losing when she includes a female protagonist after presenting the first two parts as centred upon men. This points to the importance of recognizing a redirection in gender roles in the work of postmemory. To this effect, Naïma, as the third of Hamid's four all-female children, questions the conventional preoccupation with male elder heirs as the sole representatives of histories. In fact, Naïma is pleased to notice that she naturally takes on her grandmother's gestures when she arrives in Algeria, because "Yema is Naïma's Algeria" (Zeniter 388). When she visits her relatives in the village, she is struck not by male resemblance, but by her female cousin Shrem's "familiar face," comprised of traits that are "exactly the same" (Zeniter 406) as her sister Myriem's. Thus, Naïma goes to Algeria in the hopes of seeking "proof" of her roots, and she discovers her female lineage while reconnecting to Yema's mythic remembrance and interpretation of the country. When she later returns to France and shares her photographs with the family, what resonates is Yema's amazed contemplation of the photos, which elicits a renewed recounting of Algeria as mythic fairy tale, to which Naïma herself had "retreated" whilst "on the mountain ridge" of Papa Ali's Algeria (Zeniter 427).

\section{Conclusion}

Neither Hamid nor Ali participates in Naïma's journey "back" to Algeria, and neither is present when she gathers her family to share trip photographs and re-imagine the stories of Algeria. Ali has passed away by then and Hamid continues to insist that "Algeria has nothing to do with him" (349). In this dual absence, there is a coming-to-terms with the loss of an Algeria that existed "once upon a time," one that has transferred and transformed through trauma and silence, only to reawaken and reconstruct itself through women and men of the family breaking the silence together. There is a heart-warming scene in the novel in which Naïma, upon meeting the uncles, aunts, cousins, and distant relatives that still inhabit Hamid's village, "finds herself miming, sketching her family tree in the air" (Zeniter 407). The horde of familiar strangers around her joyously collaborate, adding dozens of circles that "hang from invisible threads of family ties." The tree-makers gaze playfully and delightedly at an imaginary end product that exemplifies a "nothingness that has been traced in the air as though it were a cathedral made of lace." (408) I would like to postulate that this scene is a magnificent metaphor for personal, familial, national, and transnational memory-making. Those that do not live a history need to recognize that remembrance is sacred, delicate, and even sometimes invisible. We can begin to 
heal by retelling stories, putting into words the silenced traumas and memories that otherwise persist as hauntings. Zeniter's novel proves that it is possible to recreate and reimagine histories, by identifying and creating the concealed and obscured images behind the "nothingness."

\section{Works Cited}

Abraham, Nicolas, Maria Torok and Nicholas T. Rand. The Shell and the Kernel: Renewals of Psychoanalysis. Chicago: University of Chicago Press, 1994. Print.

Chrisafis, Angelique. "Macron Faces up to France's Colonial Past with €40m 'Harkis' Aid." The Guardian, Guardian News and Media, Sept. 2018. Web. 3 July.

$<$ www.theguardian.com/world/2018/sep/25/macron-faces-up-to-france-algeriacolonial-past-with-40m-euros-harkis-aid $>$.

Coetzee, J M. “The Mind of Apartheid: Geoffrey Cronjé (1907-)." Social Dynamics 17.1 (1991): 1-35. <https://doi.org/10.1080/02533959108458500>.

Durrant, Sam. "Introduction: Specters of Colonialism." Postcolonial Narrative and the Work of Mourning: J. M. Coetzee, Wilson Harris, and Toni Morrison, State University of New York Press, 2003: 1-22.

$<$ https://ebookcentral.proquest.com/lib/bu/detail.action?docID=3408539>.

Enjelvin, Gééraldine, and Korac-Kakabadse, Nada. "France and the Memories of "“Others"”: The Case of the Harkis." History and Memory 24.1 (2012): 152-77.

Hargreaves, Alec. "Third-Generation Algerians in France: Between Genealogy and History." The French Review 83.6 (2010): 1290-99. Print.

Hirsch, Marianne. "The Generation of Postmemory." Poetics Today 29.1 (2008): 103-28. Print.

Lever, Evelyne. "La politique algérienne du Général de Gaulle. De Brazzaville à Evian." La Politique étrangère du général de Gaulle. Ed. Élie Barnavi. Paris: Presses Universitaires de France, 1985: 148-68.

$<$ https://books.openedition.org/iheid/2002?lang=en>.

McCormack, Jo. "Social Memories in (Post)Colonial France: Remembering the Franco-Algerian War." Journal of Social History 44.4 (2011): 1129-138. Print.

Prager, Jeffrey. "Danger and Deformation: A Social Theory of Trauma Part II: Disrupting the Intergenerational Transmission of Trauma, Recovering Humanity, and Repairing Generations" in American Imago 72.2 (2015): 133- 
55. Print.

Re-writing, Re-imagining the Past (III)

Sims, Laura Jeanne. "Rethinking France's "Memory Wars"." French Politics, Culture and Society 34.3 (2016): 83-104. Print.

Zeniter, Alice. The Art of Losing. Translated by Frank Wynne. First American Edition. New York: Farrar, Straus and Giroux, 2021. Print. 